Hunn LK., and Fyhn, H. (2019). "Building and Sustaining a Culture with a Mindset for Disruptive Performance: A Case Study from Bispevika Norway" In: Proc. $27^{\text {th }}$ Annual Conference of the International. Group for Lean Construction (IGLC), Pasquire C. and Hamzeh F.R. (ed.), Dublin, Ireland, pp. 369-378. DOI: https://doi.org/10.24928/2019/0172. Available at: 〈www.iglc.net>.

\title{
BUILDING AND SUSTAINING A CULTURE WITH A MINDSET FOR DISRUPTIVE PERFORMANCE: A CASE-STUDY FROM BISPEVIKA NORWAY
}

\author{
Lars Kristian Hunn ${ }^{1}$ and Håkon Fyhn ${ }^{2}$
}

\begin{abstract}
In this case study from the building industry we present a framework for, and experiences with building and sustaining an organizational culture to create teams with a collaborative mindset for disruptive performance driven by extraordinary ambitions. It demonstrates that it is possible to develop a culture and mindset for success by actively combining concepts from social anthropology and team- and performance leadership. This is achieved by developing a cultural mythology; creating rituals for learning, developing, sharing and coordinating mindset; connecting collective and personal goals using personal goal plans; managing mindset using mindset map and digital organization charts.

The study also shows that developing organizational culture cannot only be approached as a method with structured set of rules to follow. It also needs to be acknowledged as form of craft provided by a combination of experienced leadership highly skilled in enterprise- and team development where the motivation to change is fueled by extraordinary ambitions of disruption. Last, the leaders must commit and reinvest in sustaining the culture both in economic and emotional terms. Here transparency is required, and this must be done regularly to maintain a high level of trust among all the members of the organization, so all the people can be active in developing and impacting their own culture - there is no room for bystanders.
\end{abstract}

\section{KEYWORDS}

Mindset, organizational culture, disruptive performance.

\section{INTRODUCTION}

This case study from Team Bispevika in Norway is a very large project in Norwegian context. A common view is that the construction industry is suffering from low productivity. The main contractors generate low revenue and construction work generate high costs and less value compared to other industries. (Klakegg et al. 2019). Large projects typically take 20 percent longer to finish than scheduled and are up to 80 percent over budget. Construction productivity has actually declined in some markets since the 1990s. Financial returns for contractors are often relatively low-and volatile. (Agarwal et al. 2016). Today building projects are complex, involving many different expertise and stakeholders. The industry has become more and more fragmented. Every company seems to work towards their own economic goals to secure income for themselves. Increased complexity also hampers productivity due to more difficulties communicating and collaborating efficient between different stakeholders across the value chain. (Bygg 21, 2015).

\footnotetext{
${ }^{1}$ Chief Transformation Officer, Team Bispevika AFGroup, Lars Kristian Hunn, +4790104774,

lars.kristian.hunn@afgruppen.no

${ }^{2}$ Senior researcher, NTNU Social Research, 7491 Trondheim, +47 81743561, hakon.fyhn@ ntnu.no
} 
The construction industry is facing a coming disruption where change within the industry itself increases complexity where the business environment is changing with increasing interdependencies and specialist competence (Klakegg et al 2019, Teece, 2010). This industry is also among the least digitized, where information flow is affected by the fragmentation of the industry (Rashasingham 2019). Yet, this is one of the largest industries with a significant impact on society worldwide.

What can be done in order, not only to change this trend but to transform the industry to reap the value potential in large investment building projects? The authors of this paper argue that answers are to be found, both within and outside the industry. Disruption and change is not only initiated from within a project team, but also spurred by the extraordinary ambitions on the client side; an outside factor impacting the project team from within. In other terms this describes the motivation to change as an external factor.

As this case study in certain terms is not an 'ordinary' construction project - due to size, scale and time - the complexity is higher to than most case studies on traditional construction projects in Norway. However, with time scope of 5 years the authors have a chance to follow the project team over a much longer time span than most projects - making the research not only viable for the construction industry, but for temporary network organizations as such. This makes Team Bispevika a very interesting case in terms of studying the efforts and effects of combing social anthropology and team- and performance leadership to build and sustain a culture which can meet the challenges of a contemporary organization under the pressure of meeting extraordinary ambitions of achieving maximum value creation.

The research questions and approach are developed in an on-going creative dialogue with the leaders of the organization in study, and the development of the case itself. The following research question has guided the work: How can one build and sustain a robust culture with a collaborative mindset for extraordinary performance?

This questions is divided into several sub-questions:

1 What kind of leadership, experience and deeper understanding of people and culture is required to achieve this?

2 What kind of investments is necessary to achieve this? (i.e. culture work)

3 How can extraordinary ambitions influence this goal and what kind of motivation for change can the study observe (which conditions make it meaningful to be here).

4 Can these findings lead to a higher understanding of how to create and sustain a performance culture?

5 What are the triggers for the mindset in Bispevika?

\section{METHOD}

This paper is based on an action research approach (McNiff and Whitehead 2002) where empirical studies and organizational development go hand in hand; findings of the empirical studies suggest improvement to management, if they are considered to be productive they are implemented and evaluated without further delay. As such empirical studies and implementation have moved in a continuous hermeneutic circle towards better understanding and better practice (Gadamer 1975). The empirical studies are conducted by the second author who is a social anthropologist, the methods are qualitative, based on ethnographic methodology. 
The primary method is participatory observation (Ellen 1983) where the second author took part in the activities of the Bispevika Team at the building site in periods between November 2017 and December 2019, altogether three weeks at the building site. In particular, activities connected to mindset relevant work was observed.

The observation activity implied participation in relevant activities, informal discussions with team members, making fieldnotes and giving feedback to the team, discussing and questioning the validity of the findings. Participatory observation is a method suitable for detecting the tacit dimension of interaction and the unsaid in what goes on at a workplace (Watson 1999), aspects of great importance for detecting changes in qualities of culture and mindset. In addition to observation, semi-structured, qualitative interviews were conducted with members of the team; four in the early stage of the observation period, six at the end of the period. There has been put strong emphasis on not involving the CTO in interviews in order to allow informants to feel free to criticize the leader group. A separate aspect of the action research methodology has been an on-going dialogue with the Chief Transformation Officer.

The need to re-visit the cultural work- is recognized by the leaders. In collaboration with the social anthropologist the leaders developed a survey to map the current state of the mindset and performance culture. The survey was launched in a big team meeting held in the late of February 2019. These team meeting are held about every 6th week, giving information of the current state of the project, leadership focus and on the organization as such. This survey was important in several terms. First for the team members. It showed that the team leaders take the cultural aspects seriously and are willing to re-invest again to map the state of the culture. It also showed the willingness of the leaders to get direct feedback from the organization on how the current state will give transparent knowledge on both mindset and level of performance.

Given the limited space of this paper, the authors will here focus on some of the practical implications from the results of the survey so the leaders of Team Bispevika can get feedback and new knowledge to improve the team-performance. $75 \%$ of the team members answered all the questions in the survey, which was in a digital form and fully anonymous. It investigated the level of experienced core values, level of team collaboration, experience of tools to develop the team culture, use of personal goal plan, performance and alignment of goals for the team and the individual, mindset and performance, and how the single team member can influence and be seen as an individual.

Second, the authors will also research the term mindset as such, asking the team members on how they feel about different aspects of this matter.

Third, it will give the authors a unique chance of researching and investigating on not only a large and long-term running project in the construction industry, but also the chance to develop generic knowledge which is relevant for other transformative processes.

\section{THEORY}

This case study has both a theoretical and a practical approach which is merged during a period of 18 months as an answer to the real-life challenges and obstacles of building and sustaining an organizational culture to create teams with a daredevil collaborative mindset. This section will describe how the authors use a combination of management theory and theory of social anthropology.

The theoretical approach used by Team Bispevika, was based on a concept the Chief Transformation Officer (CTO) developed which was branded "Team- and performance leadership" (see the section of case description).

This management approach was based on literature covering different aspects of both team and individual performance where alignments of both collective and individual goals is necessary for an organization to perform (Katzenbach and Smith, 1993; Wheelan 2013). The theory also emphasizes the need for team's leadership to master the skills to both set the right 
collective goals and break them down to relevant performance indicators for the individual team member so all the different tasks which need to interact to reach a required level of interdependence are all accounted for. If a group wants to become a real team, the members must be mutually dependent on each other (Bateson 1985; Fyhn 2009). Furthermore, another requirement is that the team members are mutually responsible for reaching their common goal. In other words, the ambition and goal of the collective performance must be so difficult to reach that nobody can do it by themselves (Greenberg \& Baron, 2008; Bang \& Middelfart 2014; Bakli 2016).

Another approach supplementing the above-mentioned literature is that of a more evolutionary approach to human cooperation where trust and openness is the base for successful communication, optimizing cooperation and teamwork. The true indicator for a successful team is here measured in the team's ability and capacity to revitalize its organization and sustain and transform to meet new challenges over time (Grennes 1999; Kahneman 2011; Taleb 2007).

A third strain of theory derives from military research on team dynamics, where collaboration in complex settings and the ability adapt to overcome extraordinary hardships is not only a goal, but a necessity (Alberts et al. 2001).

These three strains of theory were merged setting up the organization model and the team's performance structure during fall 2017. During the development of the organization during 2018, old school theory from classical anthropological literature where engaged in the work with the project culture. With this, concepts such as rituals (Turner 1969), storytelling and mythology (Eliade 1975), taboo (Douglas 1984), participation (Levy-Brühl 1978) and identity (Wenger 1998), where in traduced. This theoretical approach was introduced in order to develop a culture for high performance, but in the daily language of the project team, this tended to be called "mindset". The concept, mindset ended up connoting the ambitions of the culture building, thus this term is also used in the present paper.

\section{THE CASE BISPEVIKA}

The Bispevika project is one of the most ambitious and largest construction projects in Norway and aims at changing the collaborative patterns of the industry. For both Client and Contractor this is a transformation journey where the common scope of both parties is expressed in four main goals (Klagegg et al 2019).:

1. Bispevika shall become the most attractive part of the City of Oslo

2. Create the best place to live, and have the most pleased users

3. Create at least $40 \%$ more value than comparable construction projects

4. Change the collaborative patterns of the Construction Industry

To be able to reach such ambitious goals, the project owner, OSU, invited the largest construction companies to suggest how to reach performance levels beyond what is currently considered best practice in the industry the contractor, The AF Group, put together a small team of 4-6 persons that won the position as contractor, and the two parties defined the goals together. The project was set up in 2016 and is planned for completion in 2021. The business scope of the project for the Contractor is approximately $€ 1$ Billion (Klakegg et al 2019). When the AF group had won the competition, they had to put together a temporary organization - not only a project team as such - that could match these ambitions. The organization has grown gradually from the first 4-6 people in the team for conceptualizing the challenge from the client into the winning answer, 25 in the fall off 2017 and doubling to about 50 people in the winter of 2019. This being the construction industry with its fragmented value chain, the extended organization of Team Bispevika, counts 200 - 500 more people with a high number of partners and subcontractors. 
After gradually getting to know the people representing the client, the leaders of Team Bispevika grew more and more curios of why the AF team won the job, competing against far more experienced house-building teams from competitors. After being asked directly by the key-persons in Team Bispevika, Rolf Thorsen, the CEO of OSU, and his colleagues, have answered this question in numerous settings, and the answer remains the same; "Top management commitment, an innovative approach for increasing value and above all a daredevil mindset matching our ambitions".

\section{APPLICATION OF THEORY IN BISPEVIKA}

Above the authors described the merge of two different theoretical approaches, where Team Bispevika first used management theory, industry proven experience and skills to master the building of a performance culture.

This was the a priori theoretical way Team Bispevika was set up to be able to perform extraordinary as a real team, where the goal was to deliberately create a performance culture. This was a process of fall 2017, a joint effort led by the leadership team of Team Bispevika, spearheaded by the CTO and the concept of Team- and performance leadership. This concept was developed by the CTO over several years setting up a project governance model and building "High Performance Teams" for over 25 large projects in the construction industry. The concept has three main goals. First it is to simplify complexity making it easier for the project team to cope with reality. Second it is to create a high-performance team. Third, it is to align collective and individual goals and increase individual accountability and give the employee an attractive learning and career opportunity. (see table 1. for a structured overview of the concept).

Table 1. Team- and performance leadership.

\begin{tabular}{|c|c|c|c|}
\hline Goal & $\begin{array}{l}\text { Simplify } \\
\text { complex }\end{array}$ & $\begin{array}{l}\text { High performance } \\
\text { teams }\end{array}$ & $\begin{array}{l}\text { Alignment of goals. } \\
\text { Employee training } \\
\text { and individual } \\
\text { accountability }\end{array}$ \\
\hline Explanation of goals & $\begin{array}{l}\text { Create best possible } \\
\text { preconditions- businesswise } \\
\text { and organizational - for } \\
\text { performance and to reach the } \\
\text { goal of the project }\end{array}$ & $\begin{array}{l}\text { Create a real team which reach } \\
\text { the common goals of the project }\end{array}$ & $\begin{array}{l}\text { Create a sense of trust and } \\
\text { individual capability to master } \\
\text { tasks. Increase individual } \\
\text { accountability and performance. } \\
\text { Articulate an individual training } \\
\text { and career plan. Increase } \\
\text { attractivity to stay on/attract } \\
\text { new talent. }\end{array}$ \\
\hline Prepare & $\begin{array}{l}\text { Risk analysis and evaluation of } \\
\text { the needs of the project in terms } \\
\text { of business/contract } \\
\text { preconditions, technology. Map } \\
\text { the milestones and phases. } \\
\text { Make plan for execution. }\end{array}$ & $\begin{array}{l}\text { Analysis of resources to meet } \\
\text { capacity and capability } \\
\text { requirements. } \\
\text { Recruitment of team. } \\
\text { Organize the team as a network } \\
\text { of specialists. } \\
\text { Process leadership/coaching }\end{array}$ & $\begin{array}{l}\text { Map the performance potential } \\
\text { of the team using a } \\
\text { psychological tool called } \\
\text { "Jugend type index". } \\
\text { Express tasks needed to reach } \\
\text { goals. } \\
\text { Design the right governance } \\
\text { model. }\end{array}$ \\
\hline Do & $\begin{array}{l}\text { Teach key personnel the need of } \\
\text { goal alignment. Show them how } \\
\text { to express ambitions and set } \\
\text { goals. Involve - and make top } \\
\text { management accountable. Team } \\
\text { recruitment. Collaborative } \\
\text { process with client and other } \\
\text { external partners. }\end{array}$ & $\begin{array}{l}\text { Team kick off workshop. } \\
\text { Create a common goal and } \\
\text { ambition to become a real team. } \\
\text { Coach the team in } \\
\text { understanding the potential of } \\
\text { the team and each individual } \\
\text { and how to create common trust. } \\
\text { Define meeting structure and } \\
\text { map critical communication } \\
\text { hardships. }\end{array}$ & $\begin{array}{l}\text { Define individual tasks. } \\
\text { Set individual goals. } \\
\text { Self-evaluation. } \\
\text { Make personal goal-plan with } \\
\text { colleagues and leader. } \\
\text { Check that all personal goals } \\
\text { gives mutual responsibility and } \\
\text { common goal alignment. }\end{array}$ \\
\hline Follow up & $\begin{array}{l}\text { Strategic partner with the top } \\
\text { management and project } \\
\text { management. } \\
\text { Process leader of meetings, } \\
\text { workshops, client meeting. }\end{array}$ & $\begin{array}{l}\text { Evaluate team performance at a } \\
\text { regular basis at each milestone. } \\
\text { Identify treats and prioritize. } \\
\text { Fix troubles. } \\
\text { Team workshops. }\end{array}$ & $\begin{array}{l}\text { Individually } \\
\text { Monthly check in the team } \\
\text { meeting. "Am I on track?" }\end{array}$ \\
\hline
\end{tabular}




\begin{tabular}{|l|l|l|l|}
\hline & $\begin{array}{l}\text { Evaluation and performance } \\
\text { assessment. } \\
\text { Evaluation of the project for } \\
\text { scalable learning. }\end{array}$ & $\begin{array}{l}\text { In the annual employee/career- } \\
\text { plan meeting" with the } \\
\text { management. } \\
\text { Training plan/education }\end{array}$ \\
\hline $\begin{array}{l}\text { Accountability/ } \\
\text { Responsibility }\end{array}$ & $\begin{array}{l}\text { Top management and project } \\
\text { management are measured in } \\
\text { terms of both quantitative and } \\
\text { qualitative indicators. }\end{array}$ & $\begin{array}{l}\text { Top management, project leader } \\
\text { and individual. }\end{array}$ & $\begin{array}{l}\text { Individual employee } \\
\text { Project manager } \\
\text { Top management }\end{array}$ \\
\hline
\end{tabular}

In a posteriori perspective the term mindset emerged gradually to describe the special sense and feeling of a collective commitment to be all inn to accomplish the ambitions for Team Bispevika, all for one, one for all. This was not deliberately a part of the branding strategy of the leadership team.

Another a posteriori experience was the introduction of a social anthropologist, part of research consortium called KSS, companies in the construction industry cooperating with different researchers from NTNU. Here the CTO was introduced to classic theory and terms of social anthropology for the study of cultural phenomenon such as rituals, mythology, storytelling, taboo, participation and identity. All though this was not entirely unknown matter for the key persons in the leadership team and the CTO, they had not a priori incorporated these cultural tools in the design for becoming a true performance culture, only the above-mentioned tools from management theory.

Henceforth form start of 2018, all collective moments such as meetings, presentations, performance assessments and such was a part of deliberate leadership design where management theory was merged with classical theory on culture creating not only a notion of a special team - but the genesis of a myth. This increased the ability of the leadership team to a priori create the transformation of Team Bispevika to become the most innovative bunch in the construction industry. At least within their own company. This was the start of opening up the black box of the mindset to create a performance culture.

Regarding mindset, the CTO, approached the terms of his classic training in moral philosophy, and discussed the meaning of the term within the team. Here they defined it as a state of mind in which the motivation or intention of what you do, determines whether the action itself can be determined good or bad, regardless of the outcome. We will not go into an ontology and per se discussion of moral philosophy here, but the authors think this is an interesting observation on how this specific culture embraces and encourages people to try new things without being punished. According to the approach, there is only one thing you can do wrong, and that is to not ask for help.

One thing is to create a performance culture, furthermore an innovative mindset that is fueled by a collective sense of being able to reach extraordinary ambitions. Another thing is to be able to sustain that mindset maintain the belief in $40 \%$ more value creation.

During the spring and the summer of 2018, the team grew gradually. Many of the team is very young and inexperienced and the ones that are experienced are mostly not used to work in big and complex projects.

In addition to this Team Bispevika has implemented a complex planning system called Last Planner with corresponding new digital tools and extreme ambitions on behalf of all partners and sub-contractors as well (Klakegg et all, 2019). Not to mention that Team Bispevika has not only one project scope going on, but three. One for the Northern part with a traditional business model, one for the Southern part where Team Bispevika is developing a new collaborative business model with OSU, and third, a on focus for integrating all these new things learned so Team Bispevika can accelerate the transformation of the construction industry.

One year after the first team kick-off, it was by October time for the second, preparing the team for the next stage. By this time the organization had doubled in size and the project entered new phases adding more and more complexity, tasks and communication challenges 
making it more difficult to reach the required performance level. The first kick-off in 2017 had focused on "project-governance", the second focused on self-management and individual accountability and the need to re-invest in maintaining the unique mindset and culture.

The leadership group recognized a growing need to clarify structure and transparency for the team by focusing on organization development which consisted of four elements; organization charts, individual description of role and responsibility, work/role instruction and a personal goal plan.

In many terms this was precisely the same implementation of the "Team- and performance leadership" concept again, but this time also with the a priori design integrating the theory and new insights learned from social anthropology and how the phenomenon of mindset had manifested itself. The leaders were now aware of the importance of the effect of creating a myth linking individual and group in a collective collaborative where individual performance was crucial for the collective outcome.

In addition to this the CTO hired a consultant firm which has developed their own tool for mapping the state of the team/company culture. This company is called Alfa \& Omega, and they call their mapping tool "The Culture Solitaire". (https://www.alfaomega.no/).

This analysis confirmed a common view of the culture as open, innovative, experimental, ambitious and with high levels of trust, but a need for more structure, clarity of tasks and the need to run a more "tight ship". The tool also showed that all team members also wanted the same output; a winning team where everybody helps their colleagues and a culture of collective learning, experimenting and where high performance is expected. Above all this confirmed the goal of the second kick-off and nearly all went home with a up to date personal plan empowered to perform extraordinary, where all structure needed where integrated in a robust organizational design, implemented with a priori leadership design, executed as planned.

In the weeks following the second kick-off the leadership team was very focused on collaborating with their client OSU to develop a new business model and let the different teams within Team Bispevika focus on their specific tasks. Interviews were conducted with team members to see how things had developed since the second kick- off. Over all the feedback from the team members where positive regarding the state of the mindset and performance culture, but an urging need to follow up, and re-focus on the individual need seemed to be emerging again for pointing out and mapping individual and collective path, despite a success of the executing the second kick-off in a a priori way.

\section{DISCUSSION}

So here we are, in the winter of 2019, 18 months after the organization of Team Bispevika was launched.

The need to re-visit the cultural work recognized by the leaders. In collaboration with the social anthropologist the leaders developed a survey to map the current state of the mindset and performance culture. This survey was presented at a team meeting, digitally sent to all right there and all where encouraged to respond to the survey as fast as possible. Here it was made sure that it was an anonymous way of producing knowledge on the current state of the performance level and the cultural aspects of Team Bispevika.These team meetings are held about every 6 th week, giving information of the current state of the project, leadership focus and on the organization as such.

As mentioned above the authors will discuss only the most important practical implications based on the results of the survey in this paper. These discussions will be given as a feedback to the leader team, so they can use these insights to improve their own leadership in practice. If and how they do that will also be a part of the authors further research.

One of the most interesting findings was that $93 \%$ said that "I contribute to reach our goals", while $43 \%$ meant that "we contribute to reach our goals". Another finding was that 70 
$\%$ said that their own tasks and performance were aligned with the 4 main goals of the team. A third was that $90 \%$ said that they ask for help from the leaders and their colleges. A fourth was that $83 \%$ said that the personal goal plan was a good tool for improving their own performance.

In the discussions with the team leaders before the survey was sent out, the leaders meant that a majority of the team members did not lead themselves effectively. In contrast to this is the findings when the authors asked how many people that in fact had the possibility to self management and also do that in practice. Here the team members responded respectively $88 \%$ on the first question and $92 \%$ on the second. On the other hand, the leaders in advance felt that they coached and to a high degree was present as good managers and helped the individual team member to increase daily performance and to succeed with the tasks in the job. Here 58\% did not agree at all with the leaders and no team member gave full score on this topic. In addition to this the authors could see from the comments (where the team member could write in what they meant) that many wanted more feedback, more training and better on boarding (the team has grown gradually so only $40 \%$ of the team members have participated from the start of the project and $17 \%$ had not been on any kind of team building).

The preliminary findings of this discussion show that the leaders of Team Bispevika have managed to design and implement a structure that align the goals of the individual with the common goals of the project. Given the considerable changes in team size and tasks over a 18 months span this could indicate that Team Bispevika meet many important aspects of building a high performance team. It also seems as if the team members them selves mean that they function well in their roles doing their own tasks.

On the other hand, the same people think that a much smaller degree of their collogues contribute to reach the same common goals. Further they also say that the leaders could improve on following up the individual goal plan in a better way, although a vast majority of the people have a goal plan which they have made together with their leader.

This survey will be important in several terms. First for the team members. It will show the that the team leaders take the cultural aspects seriously and are willing to re-invest again to map the state of the culture. It will also show the willingness of the leaders to get direct feedback from the organization on how the current state will give transparent knowledge on both mindset and level of performance.

Second, the leaders will have knowledge - based on research -, not feelings, on where and how to act to improve team performance. The authors think that this can be a good example on how organizations can improve performance in real time - making collaboration between the construction industry and research more relevant for increasing productivity on a short-term basis in a specific context.

Third, the authors will also further research the term mindset as such, asking the team members on how they feel about different aspects of this matter.

Forth, it will give the authors a unique chance of researching and investigating on not only a large and long-term running project in the construction industry, but also the chance to develop generic knowledge which is relevant for other transformative processes.

This story is also a case of action research, combing both management theory, social anthropology with insights and skills of experienced leaders. This can result in a more nuanced research design, able to tackle real world challenges, adding value by developing better a priory strategies for creating and sustaining the needed mindset and performance levels required of a culture that must change all the time. (Klakegg et al., 2019). It is a matter of being able to disrupt or be disrupted. There is also a growing general recognition of the importance of mindset and culture as $\mathrm{x}$-factor for succeeding in organizational shifts from hierarchy to a collaborative network-based model.

In terms of practical contribution the findings of all aspects of this research - not only the survey - can boost the performance of the project organization by helping the leaders in

Commented [HF1]: Flytta alt dette fdra introduksjonen. Er ikke helt sikker på dette grepet, men tror det passer bedre her. 
Team Bispevika increase their own knowledge in mindset and culture. This awareness should also develop the quality of how they in practical manage their own team and coach the team members in a more effective way, increasing both individual and collective performance. The contribution in generic terms should be relevant for all kind of organizations, not only temporary such as projects, where the motivation to change is driven by the need to stay competitive and in the end, not be put out of business by external disruption due to changes in the value chain. Innovation in many terms means the ability to change, not only once, but continuously. This is why you need a robust culture which can perform under pressure and actually make it possible to avoid disruption by being able to learn and change and sustain innovation over time.

In theoretical terms the authors hope the combination of two theoretical approaches combined with industry proven experiences leaders will contribute to a more nuanced discussion on why culture and mindset need to be integrated with management theory (Klakegg et al 2019). The case study is a unique opportunity as a laboratory for developing knowledge on culture and team performance. Here the authors will further investigate how mindset as a phenomenon can be of significance to help organizations succeed with collaboration and innovation over time.

The findings in this paper is off course limited by that the case study itself. This is a story of an organization that still is writing and re-writing its history as it evolving as a cultural phenomenon, impacting both inside and outside Team Bispevika. In many terms this case study is a real-time laboratory of the emerging and evolvement of a culture.

\section{CONCLUSION}

This case study shows that collaboration between researchers and industry proven leaders can be fruitful. It also tells us that a multidisciplinary approach is necessary in order to understand the impact extraordinary ambitions as a motivating factor for transformation. It also indicates the need to find new approaches in order to actually create a culture able to handle a transformative setting. It also gives indications to why one must revisit - all the time - and investigate the context and preconditions for learning, giving a better chance of actually create a performance culture, not once, but always. This requires not only repeated investments in terms of money, but also in transparency and accountability on behalf of the leaders.

The study further shows that systematic work on collective mindset is possible and it is possible to grasp the "slippery" phenomenon called culture. Exact implications from Bispevika: strong collective mindset, ability to learn and transform rapidly and the necessity to re-invest in building strong teams to reach extraordinary performance level.

There is still a need for further research in order to unlock "the black box" of performance culture. This calls for in dept studies over time of cultural development in temporary organizations such as construction projects. The next step for the authors will be to further analyze the findings of the survey, explore the phenomenon of mindset, share the insights in the extended network of Team Bispevika's industry clusters, The authors will also discuss and get feedback at the IGLC conference of 2019 and follow the development in the story of Team Bispevika where the ambition of the authors is to wright an article which in more depth can cover the aspects of mindset, organizational culture and disruptive performance.

\section{REFERENCES}

Agarwal, Rajat. Chandrasekaran, Sridhar, Mukund. 2016: Imagening construction's digital future. McKinsey Insights Report. McKinsey\&Company.

Alberts, David S. David S ; Garstka, John J ; Hayes, Richard E ; Signori, David A. 2001: Understanding Information Age Warfare. Washington D.C. CCRP 
Bang, H. \& Middelfart, T.N. 2012: Effektive ledergrupper. Oslo, Gyldendal Akademisk.

Bakli, G. L. 2016: Goal setting Contractor's Project Teams. Master thesis, NMBU.

Bateson, Gregory. 1985 [1972]: Steps to an ecology of mind. Collected essays in anthropology, psychiatry, evolution, and epistemology. Ballantine Books. New York.

Bygg 21, 2015. Neste steg. Bygg 21.

Douglas, Mary. 1984: Purity and danger: an analysis of concepts of pollution and taboo. London: Ark Paperbacks.

Eliade, Mircea. 1975: Myth and Reality. New York: Harper \& Row Publishers.

Fyhn, Håkon. 2009: “Kreativ tverrfaglighet”. I Kreativ tverrfaglighet, teori og praksis. Red. H. Fyhn. Trondheim: Tapir Akademisk Forlag.

Gadamer, H. G. (1975) "Hermeneutics and Social Science". Philosophy Social Criticism / Cultural Hermeneutics. 2 (4): 307-316.

Greenberg, J., \& Baron, R.A. 2008: Behavior in organizations. New Jersey, Pearson Educational International.

Grennes, Carl Erik. 1999: Kommunikasjon i organisasjoner. Abstrakt Forslag A/S. Holy, Ladislav. 1983: "Theory, method and the research process." I Ethnographic Research, A Guide to a General Conduct. Red. R. F. Ellen. London: Academic Press, Harcourt Braise Javanovich, Publishers.

Kahnemann, Daniel. 2011: Thinking fast and slow. Farrar, Straus and Giroux.

Katzenbach, Jon R and, Smkith, Douglas. K. 2010: The wisdoms of teams: Creating the HighPerformance Organization. Harvard Business Review Press.

Klagegg, Ole Jonny, Lars Kristian Hunn, Per Fridtjof Larssen. 2019: Bispevka Project Research for constructing a collaborative value chain. Emerald reach publishing services.

Levy-Brühl, Lucien. 1978: The Notebook on Primitive Mentality. Oversatt av P. Rivière. London: Harper \& Row Publishers.

McNiff, Jean \& Whitehead, Jack. 2002: Action Research: Principles and Practice. Cambridge: Cambridge University Press.

Rashasingham, Kamalan. 2019: Digitisation in the construction industry. Master thesis University of Oslo.

Taleb, Nassim Nicholas. 2007: The Black Swan: The Impact of the Highly Improbable. Random House Allan Lane.

Turner, Victor. 1969: The Ritual Process, Structure and anti Structure. Aldine. Chicago.

Watson, C. W. (Red.) 1999: Being There. Fieldwork in Anthropology. London: Pluto Press.

Wheelan, Susan A. 2013: Creating effective teams. Sage Publications.

Wenger, Etienne. 1998: Communities of Practice; Learning, Meaning and Identity. New York: Cambridge University Press. 